\title{
The Synthesis of Pyrazole Derivatives Based on Glucose
}

\author{
Kui Du, Yi-Jia Mei, Xian-Ting Cao, Peng-Fei Zhang, and Hui Zheng
}

\begin{abstract}
Heterocyclic compounds and glucose derivatives play important role in organic chemistry and biological chemistry for their richc functionality. A facile and convient protocol had been developed for the synthesis of a series of novel glucosyl pyrazole derivatives starting from D-glucose. The protected glucose by O-pivaloyl groups reacted with BTC and obtained corresponding 2-isocyanate glucose, which effectively avoid the harsh conditions and highly toxic agents compared to the traditional method. Glucosyl pyrazole derivatives were then prepared through the reaction of pyrazole and its derivatives with 2 -isocyanate glucose with good yields.
\end{abstract}

Index Terms-Heterocycle, glucose, pyrazole, synthesis.

\section{INTRODUCTION}

Pyrazoles are chemical compounds of synthetic origin that have a five-membered heterocycle with two nitrogen atoms and three adjacent carbons. Pyrazole derivatives, several members of the pyrazoles class, have shown good pharmacological effects or have the potential biological activities, such as, anti-inflammatory [1], antiviral [2], antimicrobial [3], anticonvulsant [4], antitumor [5], fungicidal activities [6] and antihistaminic [7]. The pyrazole moiety has important role in some drugs structure, for example, some arylpyrazole derivatives have anti-HIV-1 activity [8]-[10] and some pyrazole-3-carbox- amide moiety has anti-CB1 cannabinoid ability [11]. In addition, the pyrazole derivatives have many applications on crop protection chemistry. There were many herbicidally, fungicidally and insecticidally active pyrazole classes in this field (Fig. 1). So pyrazole derivatives have attracted much attention of chemists.

D-glucose is one of the most important energy sources for the survival of various organisms [12]. Organic compounds which containing glycoconjuates owing to their essential roles in a lot of physiological processes and to their potential applications as tumor receptors and antibodies. The glycoconjugates also exerted important effects on many complex biological events, including cellular recognition in the processes of immune response, inflammation, tumor metastasis, and viral infections [13]. In addition, glycosylation of proteins and lipids is a key factor in modulating their structures and functions [14]. However, there are a few reports on the synthesis and pharmacology of the pyrazole derivatives containing sugar moieties.

Manuscript received February 25, 2013; revised June 17, 2013. This work was supported by National Natural Science Foundation of China (No 21106026), Key Sci-tech Innovation Team of Zhejiang Province (No. 2010R50017) and HNUEYT (2011-01-13).

The authors are with the Hangzhou Normal University, Hangzhou 310036 China (e-mail:5584892598@qq.com,562818116@qq.com, 459209401@qq.com, 1304112697@qq.com, huizheng@hznu.edu.cn).

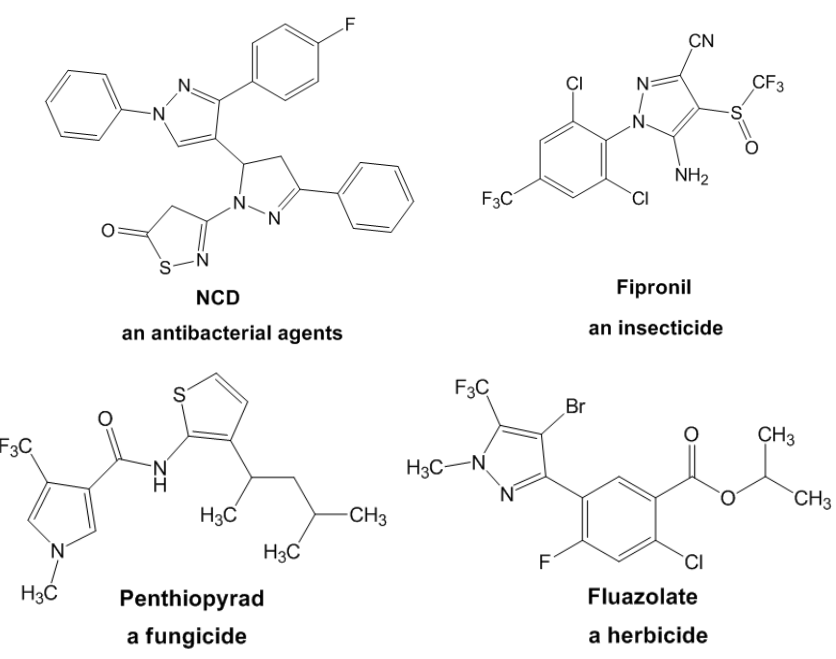

Fig. 1. Some pyrazole derivatives

Encouraged and enlightened by the importance of D-glucose in nature and the bioactivity of pyrazole derivatives, herein, we report a facile and efficient method of preparing the pyrazole derivatives on glucose. (Fig. 2).

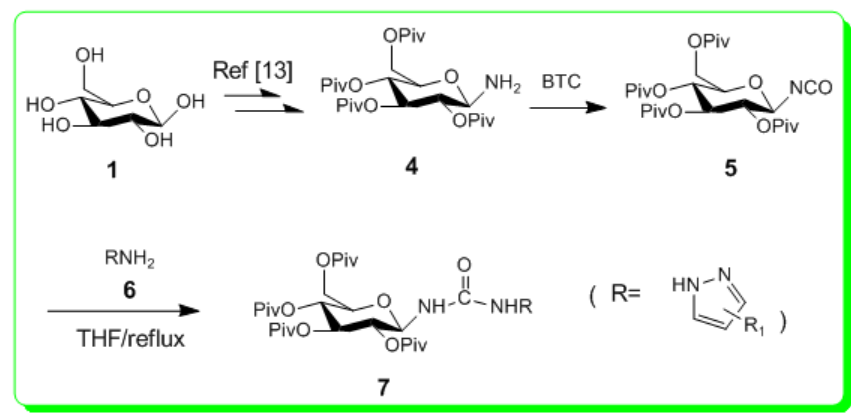

Fig. 2. Synthesis of D-glucopyrancse derivatives 7a-7f

\section{RESULTS AND DISCUSSION}

During our previous research [15], we have developed a novel route for the synthesis of ( $2 \mathrm{R}, 3 \mathrm{~S}, 4 \mathrm{~S}, 6 \mathrm{R})$-2-amino-6(pivaloyloxymethyl)tetrahydro-2H-pyran-3,4,5-triyl tris(2, 2- dimethylpropanoate) 4 starting from D-glucose. Prompted by these results and in continuation of our search for bioactive molecules, we planed to synthesis some pyrazole derivatives based on glucose by the reaction of glycosyl isocyanate 5 with the different amines 6 . Generally speaking, the preparation of isocyanate was using high toxic phosgene. Here we employed the triphosene (BTC) and made it react with 4 and obtained the compound 5. Compared with conventional methods, the use of BTC allowed us to be more convenient and easier to operate in experiments with good yields. And then the synthesis of the novel compounds 7 were accomplished by the reaction of pyrazole and its derivatives 6a-6f with the 2-isocyanate glucose 5 to give the 
D-glucopyrancse derivatives $7 \mathrm{a}-7 \mathrm{f}$ with $17 \%-73 \%$ yields in mild reaction conditions.

A detailed study of different substrates was performed toward the formation of glucose-based pyrazole derivatives (Table 1). To investigate the influence of stereo and electronic effect about the substrate 6 toward the formation of glucose-based pyrazole derivatives 7 , methyl and phenyl groups were chosen for $\mathrm{R}$ substituents as representatives of alkyl and aryl group in the vicinity of the $3-\mathrm{NH}_{2}$ reactive centre of substrate 6 . At the same time, the fully unsubstituted pyrazole ring $1 \mathrm{H}$-pyrazol-3-amine $6 \mathrm{a}$ was also considered to be the model substrate to identify the method of choice for glycosylation.

From the experimental results, it was found that the yield is relatively high $(73 \%)$ when there are no substituents on the pyrazole ring ( $7 \mathrm{a}$, Table I). On the contrary, the yield is low when there are some substituents at pyrazole ring such as methyl group, nitrile group and phenyl group. Initially, we just want to investigate the influence of electron effect coming from different groups. While the experimental results revealed that the steric effects maybe played dominant role. Because the D-glucose which be protected by O-pivaloyl groups itself is a large steric hindrance group, and with the increases of the substituted groups at pyrazole ring, the steric hindrance on pyrazole ring increases accordingly, so the reactive activity of compound 6 decreased and the yields of $7 \mathrm{~b}-7 \mathrm{f}$ were declining correspondingly from $64 \%-17 \%$.

TABLE I: CHEMICAL STRUCTURE OF THE TITLE COMPOUNDS

Compd

${ }^{\mathrm{a}}$ Isolated yield

All the products were confirmed by IR, ${ }^{1} \mathrm{H}$ NMR, ${ }^{13} \mathrm{C}$ NMR and MS. The IR spectrum exhibited absorption bands at $3435 \mathrm{~cm}^{-1}$ and $2950 \mathrm{~cm}^{-1}$, indicating the presence of N-H and $\mathrm{C}-\mathrm{H}$ groups of the pyrazole ring, while absorption at $1740 \mathrm{~cm}^{-1}$ indicated the presence of carbonyl of the sugar ketone groups. In the ${ }^{1} \mathrm{H}$ NMR spectrum hydrogen of pyrazole ring and multiplet of the glucose ring were observed at about $\delta 7.3 \mathrm{ppm}$ and $\delta 4.89 \mathrm{ppm}$, respectively. The typical signals on ${ }^{13} \mathrm{C}$ NMR spectrum of carbonyl group in acetyl showed from $\delta 178.20 \mathrm{ppm}$ to $153.06 \mathrm{ppm}$ and the shift values from about $\delta 140 \mathrm{ppm}$ to $70 \mathrm{ppm}$ proved the existence of pyrazole ring. The biological screen of these compounds will be performed in next research work.

\section{A. Experimental}

All the reagents used without any further purification. The solvents were purified according to the standard methods. Analytical TLC was performed on a Merck precoated TLC (Silica Gel 60 F254) plate. Melting points were recorded on an $\mathrm{X}_{4}$-Data microscopic melting point apparatus and are uncorrected. IR spectra were recorded on a Bruker Equinox-55 spectrophotometer using $\mathrm{KBr}$ discs in the $4000-400 \mathrm{~cm}^{-1}$ region. MS were acquired on a Bruker Esquire 3000 plus spectrometer. ${ }^{1} \mathrm{H}$ and ${ }^{13} \mathrm{C}$ NMR were recorded on a Bruker Avance 400 spectrometer in $\mathrm{CDCl}_{3}$ using TMS as internal standard.

\section{B. General Procedure for the D-glucosepyranose Derivatives}

A typical experimental procedure for D-glucosepyranose derivatives 7a was as follows. A mixture of 3-aminopyrazole $6 \mathrm{a}(0.0415 \mathrm{~g}, 0.5 \mathrm{mmol})$ and D-pyranoid glucose isocyanate $5(0.2750 \mathrm{~g})$ in $5 \mathrm{~mL}$ anhydrous THF solution was incubated in the round bottomed flask, then reflux for $4 \mathrm{~h}$, The reaction was further stirred until the disappearance of starting material. The residue was evaporated and the product $7 \mathrm{a}$ was purified using column chromatography ((10:1 ethyl acetate/MeOH).

(2R, 3S， 4S， 6R)-2-(3-(1H-pyrazol-3-yl)ureido) -6-((pivaloyloxy)methyl)tetrahydro-2H-pyran-3,4,5-triyltris( 2,2-dimethylpropanoate) (7a): yield 73\%; IR ( $\mathrm{KBr}, \mathrm{cm}-1)$ : 3435, 2950, 1740, 1455, 1300, 1150, 1050; MS (ESI): m/z $(\%)$ : $624.72[\mathrm{M}+1]+; 1 \mathrm{H} \mathrm{NMR}(\mathrm{CDCl} 3): \delta 7.93-7.95(m, 1 \mathrm{H})$, $7.43(d, J=10.0 \mathrm{~Hz}, 1 \mathrm{H}), 7.28-7.30(m, 1 \mathrm{H}), 5.81(d, J=$ $3.2 \mathrm{~Hz}, 1 \mathrm{H}), 5.44(t, J=6.4 \mathrm{~Hz}, 2 \mathrm{H}), 5.28(t, J=6.3 \mathrm{~Hz}, 1 \mathrm{H})$, $5.19(t, J=6.3 \mathrm{~Hz}, 1 \mathrm{H}), 5.13(t, J=6.4 \mathrm{~Hz}, 1 \mathrm{H}), 4.15-4.19(\mathrm{~m}$, $2 \mathrm{H}), 3.89(d, J=10.0 \mathrm{~Hz}, 2 \mathrm{H}), 1.12-1.20(m, 36 \mathrm{H})$; $13 \mathrm{C} \mathrm{NMR}$ (CDCl3): $\delta 178.10,177.76,176.99,176.31,156.43,149.53$, $130.13,99.68,79.58,74.13,72.25,70.16,67.45,61.56$, $38.89,39.77,27.14,26.84$.

(2R, 3S, 4S, 6R)-2-(3-(4-cyano-1H-pyrazol-3-yl)ureido) -6-((pivaloyloxy)methyl)tetrahydro-2H-pyran-3,4,5-triyl-tris (2,2-dimethylpropanoate) (7b): yield: 64\%; IR $\left(\mathrm{KBr}, \mathrm{cm}^{-1}\right)$ : 3435, 2950, 2210, 1740, 1455, 1300, 1150, 1050, 950; MS(ESI): $\mathrm{m} / \mathrm{z}(\%): 649.73[\mathrm{M}+1]^{+} ;{ }^{1} \mathrm{H}$ NMR $\left(\mathrm{CDCl}_{3}\right): \delta$ 7.50-7.52 ( $m, 1 \mathrm{H}), 7.43-7.45(m, 1 \mathrm{H}), 7.00-7.22(m, 1 \mathrm{H})$, 6.13-6.17 $(m, 1 \mathrm{H}), 5.44-5.46(m, 1 \mathrm{H}), 5.39(t, J=9.2 \mathrm{~Hz}, 1 \mathrm{H})$, $5.18(t, J=6.3 \mathrm{~Hz}, 1 \mathrm{H}), 5.13(t, J=10.0 \mathrm{~Hz}, 1 \mathrm{H}), 4.88-4.91(m$, $2 \mathrm{H}), 4.10-4.13(m, 2 \mathrm{H}), 2.29-2.30(m, 1 \mathrm{H}), 1.10-1.20(\mathrm{~m}$, $36 \mathrm{H}) ;{ }^{13} \mathrm{C} \mathrm{NMR}\left(\mathrm{CDCl}_{3}\right): \delta 178.20,178.05,176.86,176.46$, $153.40,149.53,145.34,138.45,137.90,135.00,129.45$, $90.74,79.82,73.84,72.12,70.48,67.54,70.16,61.66,38.91$, $39.99,26.89$.

(2R， 3S， 4S， 6R)-2-(3-(5-phenyl-1H-pyrazol-3-yl) ureido)-6-((pivaloyloxy)methyl)tetrahydro-2H-pyran-3,4,5-t riyl-tris(2,2-dimethylpropanoate) (7c): yield: 57\%; IR (KBr, $\mathrm{cm}^{-1}$ ): 3435, 2950, 1740, 1530, 1455, 1300, 1150, 1050, 950; MS(ESI): $\mathrm{m} / \mathrm{z}(\%): 701.00[\mathrm{M}+1]^{+} ;{ }^{1} \mathrm{H}$ NMR $\left(\mathrm{CDCl}_{3}\right): \delta$ 9.15-9.16 $(m,, 1 \mathrm{H}), 8.01(d, J=8.4 \mathrm{~Hz}, 2 \mathrm{H}), 7.83(d, J=$ 
$7.2 \mathrm{~Hz}, 2 \mathrm{H}), 7.42-7.44(m, 1 \mathrm{H}), 6.72(s, 1 \mathrm{H}), 5.48-5.50(m$, $2 \mathrm{H}), 5.41-5.42(m, 1 \mathrm{H}), 5.25-5.27(m, 1 \mathrm{H}), 5.23-5.25(m$, $1 \mathrm{H}), 5.27-5.29(\mathrm{~m}, 1 \mathrm{H}), 4.18-4.20(\mathrm{~m}, 2 \mathrm{H}), 3.93(d, J=$ $10.0 \mathrm{~Hz}, 2 \mathrm{H}), 1.12-1.22(m, 36 \mathrm{H}) ;{ }^{13} \mathrm{C}$ NMR $\left(\mathrm{CDCl}_{3}\right)$ : $\delta 178.13,177.92,177.03,176.37,153.06,152.55,150.20$, $132.03,128.99,128.57,126.10,86.39,70.42,74.11,72.18$, $70.10,67.52,67.45,61.50,47.54,38.48,28.63$.

(2R, 3S, 4S, 6R)-2-(3-(1,5-dimethyl-3-oxo-2-phenyl-2, 3-dihydro-1H-pyrazol-4-yl)ureido)-6-((pivaloyloxy)methyl) tetrahydro-2H-pyran-3,4,5-triyl( tris(2,2-dimethylpropanoat e) (7d): yield: $21 \%$; IR $\left(\mathrm{KBr}, \mathrm{cm}^{-1}\right): 3435,2950,1740,1513$, 1488, 1462, 1321, 1236, 1088, 950; MS(ESI): m/z (\%): $744.87[\mathrm{M}+1]^{+} ;{ }^{1} \mathrm{H}$ NMR $\left(\mathrm{CDCl}_{3}\right): \delta 7.93-7.94(m, 1 \mathrm{H}), 7.43$ $(d, J=10.0 \mathrm{~Hz}, 1 \mathrm{H}), 7.28-7.31(m, 1 \mathrm{H}), 5.81(d, J=3.2 \mathrm{~Hz}$, $1 \mathrm{H}), 5.44(t, J=6.4 \mathrm{~Hz}, 2 \mathrm{H}), 5.28(t, J=6.3 \mathrm{~Hz}, 1 \mathrm{H}), 5.19(t, J$ $=6.3 \mathrm{~Hz}, 1 \mathrm{H}), 5.13(t, J=6.4 \mathrm{~Hz}, 1 \mathrm{H}), 4.15-4.17(m, 2 \mathrm{H}), 3.89$ $(d, J=10.0 \mathrm{~Hz}, 2 \mathrm{H}), 1.19-1.25(m, 36 \mathrm{H}) ;{ }^{13} \mathrm{C} \mathrm{NMR}\left(\mathrm{CDCl}_{3}\right)$ : $\delta 178.10,177.76,176.99,176.31,156.43,149.53,130.13$, 99.68, 79.58, 74.13, 72.25, 70.16, 67.45, 61.56, 39.92, 29.67 .

$(2 \mathrm{R}$, $3 \mathrm{~S}$, $4 \mathrm{~S}$, 6R)-2-(3-(3-methyl-1-phenyl-1H-pyrazol-5-yl) ureido)-6-((pivaloyloxy)methyl)tetrahydro-2H-pyran-3,4,5-t riyltris(2,2-dimethylpropanoate)(7e): yield: 17\%; IR ( $\mathrm{KBr}$, $\left.\mathrm{cm}^{-1}\right): 3435,2950,1741,1513,1498,1463,1321,1236$, 1088, 950. MS(ESI): $\mathrm{m} / \mathrm{z}(\%): 714.85[\mathrm{M}+1]^{+} ;{ }^{1} \mathrm{H}$ NMR $\left(\mathrm{CDCl}_{3}\right): \delta$ 7.84-7.86 $(\mathrm{m}, 1 \mathrm{H}), 7.45-7.47(\mathrm{~m}, 2 \mathrm{H}), 7.29-7.31$ $(m, 2 \mathrm{H}), 6.42(s, 1 \mathrm{H}), 6.10-6.13(m, 1 \mathrm{H}), 5.40-5.42(m, 1 \mathrm{H})$, $5.19(t, 1 \mathrm{H}), 5.10-5.13(m, 1 \mathrm{H}), 5.19-5.21(\mathrm{~m}, 2 \mathrm{H}), 4.81(t, J$ $=9.6 \mathrm{~Hz}, 1 \mathrm{H}), 4.10-4.12(m, 1 \mathrm{H}), 3.85(s, 1 \mathrm{H}), 2.41-2.42$ $(m, 1 \mathrm{H}), 2.25-2.27(m, 1 \mathrm{H}), 2.18(s, 3 \mathrm{H}), 1.17-1.20(m, 36 \mathrm{H})$; ${ }^{13} \mathrm{C} \mathrm{NMR}\left(\mathrm{CDCl}_{3}\right): \delta 178.07,177.03,176.85,176.45,153.68$, $149.55,149.37,145.53,138.35,137.94,129.12,129.17$, $124.55,123.81,90.55,79.70,73.77,72.37,70.45,67.53$, $61.74,39.93,28.69$.

(2R, 3S, 4S, 6R)-2-(3-(1-methyl-1H-pyrazol-3-yl)ureido) -6-((pivaloyloxy)methyl)tetrahydro-2H-pyran-3,4,5-triyl-tris (2,2-dimethylpropanoate) (7f): yield: $45 \%$; IR $\left(\mathrm{KBr}, \mathrm{cm}^{-1}\right)$ : 3435, 2950, 1741, 1513, 1498, 1463, 1321, 1236, 1083, 953; MS(ESI): m/z (\%): $638.75[\mathrm{M}+1]^{+},{ }^{1} \mathrm{H}$ NMR $\left(\mathrm{CDCl}_{3}\right): \delta$ $7.80-7.82(\mathrm{~m}, 1 \mathrm{H}), 7.43(d, J=10.0 \mathrm{~Hz}, 1 \mathrm{H}), 7.29-7.31(\mathrm{~m}$, $1 \mathrm{H}), 5.03-5.05(m, J=3.2 \mathrm{~Hz}, 1 \mathrm{H}), 5.44-5.45(m, 1 \mathrm{H})$, 5.28-5.29 (m, 1H), 5.19-5.21 (m, 1H), 5.13-5.15 (m, 1H), 4.15-4.16 ( $m, 2 \mathrm{H}), 3.91-3.93(m, 1 \mathrm{H}), 1.16-1.25(m, 36 \mathrm{H})$; ${ }^{13} \mathrm{C} \mathrm{NMR}\left(\mathrm{CDCl}_{3}\right): \delta 178.09,177.74,176.85,176.35,176.15$, $149.55,130.43,99.78,79.58,74.13,72.25,70.16,67.45$, $61.56,40.22,29.92$.

\section{CONCLUSION}

In conclusion, we developed a facile and convient protocol for the synthesis of glucosyl pyrazole derivatives starting from D-glucose. This method avoids using the harsh reaction conditions and highly toxic agents compared to the traditional method, which provides a effective method to synthesize the sugar-heterocyclic derivatives.

\section{REFERENCES}

[1] A. K. Tewari and A. Mishra, "Synthesis and anti-inflammatory activities of N4, N5-disubstituted-3-methyl-1H-pyrazolo [3, 4-c]pyrida-zines," Bioorg. Med. Chem., vol. 9, pp. 715-718, 2001.

[2] S. L. Janus, A. Z. Magdif, B. P. Erik, and N. Claus, "Synthesis of triazenopyrazole derivatives as potential inhibitors of HIV-1," Monatsh. Chem., vol. 130, pp. 1167-1174, 1999.

[3] E. V. Pimerova and E. V. Voronina, "Antimicrobial activity of pyrazoles and pyridazines obtained by interaction of 4-aryl-3-arylhydrazono-2, 4-dioxobutanoic acids and their esters with hydrazines," Pharm. Chem. J., vol. 35, pp. 602-604, 2001.

[4] I. Bouabdallah, L. A. Barret, A. Zyad, A. Ramadan, I. Zidane, and A. Melhaoui, "Anticancer effect of three pyrazole derivatives," Nat. Prod. Res., vol. 20, pp. 1024-1030, 2006.

[5] H. J. Park, K. Lee, S. J. Park, B. Ahn, J. C. Lee, H. Y. Cho, and K. I. Lee, "Identification of antitumor activity of pyrazole oxime ethers," Bioorg. Med. Chem. Lett., vol. 15, pp. 3307-3312, 2005.

[6] C. K. Chu and J. J. Cutler, "Chemistry and antiviral activities of acyclonucleosides," Heterocycl. Chem., vol. 23, pp. 289-319, 1986.

[7] V. Michon, C. H. Du Penhoat, F. Tombret, J. M. Gillardin, F. Lepagez, and L. Berthon, "Preparation, structural analysis and anticonvulsant activity of 3- and 5-aminopyrazole N-benzoyl derivatives," Eur. J. Med. Chem., vol. 30, pp. 147-155, 1995.

[8] M. J. Genin, C. Biles, B. J. Keiser, S. M. Poppe, S. M. Swaney, W. G. Tarpley, Y. Yagi, and D. L. Romero, "Novel 1,5-Diphenylpyrazole Non-nucleoside HIV-1 Reverse Transcriptase Inhibitors with Enhanced Activity versus the Delavirdine-Resistant P236L Mutant: Lead Identification and SAR of 3- and 4-Substituted Derivatives," J. Med. Chem., vol. 43, pp. 1034-1040, 2000.

[9] Y. R. Huang and J. A. Katzenellenbogen, "Regioselective synthesis of 1,3,5-triaryl-4-alkylpyrazoles: novel ligands for the estrogen receptor," Org. Lett., vol. 2, pp. 2833-2836, 2000.

[10] S. R. Stauffer, C. J. Coletta, R. Tedesco, G. Nishiguchi, K. Carlson, J. Sun, B. S. Katzenellenbogen, and J. A. Katzenellenbogen, "Pyrazole Ligands: Structure-Affinity/Activity Relationships and Estrogen Receptor- $\alpha$-Selective Agonists," J. Med. Chem., vol. 43, pp. 4934-4947, 2000.

[11] S. Ruiu, G. A. Pinna, G. Marchese, J. M. Mussinu, P. Saba, S. Tambaro, P. Casti, R. Vargiu, and L. Pani, "Synthesis and characterization of NESS 0327: A novel puta tive antagonist of the CB1 cannabinoid receptor," J. Pharm. Exp. Ther., vol. 306, pp. 363-370, 2003.

[12] K. C. Nicolaou and H. J. Mitchell, "Adventures in carbohydrate chemistry: new synthetic technologies, chemical synthesis, molecular design, and chemical biology," Angew. Chem. Int. Ed., vol. 40, pp. 1576-1624, 2001.

[13] P. M. Rudd, T. Elliott, P. Cresswell, I. A. Wilson, and R. A. Dwek, "Glycosylation and the Immune System," Science, vol, 291, pp. 2370-2376. 2001.

[14] B. G. Davis, "Synthesis of Glycoproteins," Chem. Rev., vol, 102, pp. 579-562, 2002.

[15] G. B. Zhou, P. F. Zhang, and Y. J. Pan, "A novel method for synthesis of arylacetic acids from aldehydes, N-(2,3,4,6-tetra-O-pivaloylated-Dglucopyranosyl) amine and trimethylsilyl cyanide," Tetrahedron., vol. 61 , pp. 5671-5677, 2005.

Kui Du was born in Hubei province on December 11 1986. He got his bachelor degree at Hubei University of Arts and Science, and will get his master degree at June next year. He is interested in the synthesis of heterocycle. 